\title{
A Significant Number of Charter Diplomates Participate in American Board of Family Medicine (ABFM) Maintenance of Certification
}

\author{
James C. Puffer, MD
}

Considerable controversy about the value of participating in Maintenance of Certification has recently arisen within the medical community. Despite this controversy, large numbers of family physicians certified by the American Board of Family Medicine participate in Maintenance of Certification for Family Physicians. Surprisingly, a small but significant number of charter diplomates-those initially certified by the American Board of Family Medicine at its founding - are engaged in the process. ( $\mathrm{J}$ Am Board Fam Med 2015;28:439-440.)

Keywords: Certification, Health Policy

When the American Board of Family Medicine (ABFM) was approved as the 19th medical specialty board in the United States by the American Board of Medical Specialties in 1969, its founding fathers established several important principles that would govern certification in the specialty. Perhaps the most important of these were 2 critical decisions. First, no one would be grandfathered into the specialty; a family physician, regardless of experience or time in practice, could become certified only by passing an initial certification examination. Second, every physician earning certification would be issued a time-limited certificate and would be required to recertify at least every 7 years. ${ }^{1}$ Those 1690 family physicians who certified in 1970 and the 1595 who earned certification in 1971 were considered to be charter diplomates of the ABFM.

Many have recently criticized the value of Maintenance of Certification (MOC), and physicians in

This article was externally peer reviewed.

Submitted 21 January 2015; revised 1 April 2015; accepted 7 April 2015.

From the American Board of Family Medicine, Lexington, KY.

Funding: none.

Conflict of interest: JCP is an employee of the American Board of Family Medicine.

Corresponding author: James C. Puffer, MD, American Board of Family Medicine, 1648 McGrathiana Parkway, Suite 550, Lexington, KY 40511-1247 (E-mail: jpuffer@ theabfm.org). many specialties have made the decision not to participate. $^{2}$ Despite this fact, participation in MOC for family physicians (MC-FP) by family physicians remains robust. ${ }^{3,4}$ Using ABFM administrative data, we wanted to determine the number of charter diplomates who were still meeting the requirements of MC-FP more than 40 years after their initial certification.

Thirty-nine diplomates (2.3\%) certified in 1970 remain engaged in MC-FP, and 53 charter diplomates $(3.3 \%)$ certified in 1971 are similarly meeting MC-FP requirements (Figure 1). Those participating charter diplomates from the 1970 cohort range in age from 72 to 94 years of age, with a mean age of 79 years. Those family physicians in the 1971 cohort still participating in MC-FP range in age from 70 to 87 years, with a mean age of 74 years. On average, the charter diplomates in these cohorts have taken the ABFM examination 6 times, and a few have taken it on 7 occasions.

Despite the challenges that many specialties are facing with regard to the implementation of MOC, participation in this process by board-certified family physicians has been consistent with the historic participation rates seen in the ABFM's original recertification paradigm. ${ }^{5}$ Participation in MC-FP by those charter diplomates initially certified over 40 years ago serves as testimony to the wisdom demonstrated by ABFM's founders when they established the tenets that would guide the certification process of the specialty. 
Figure 1. Charter diplomates initially certified in 1970 or 1971 still participating in Maintenance of Certification for Family Physicians (MC-FP).

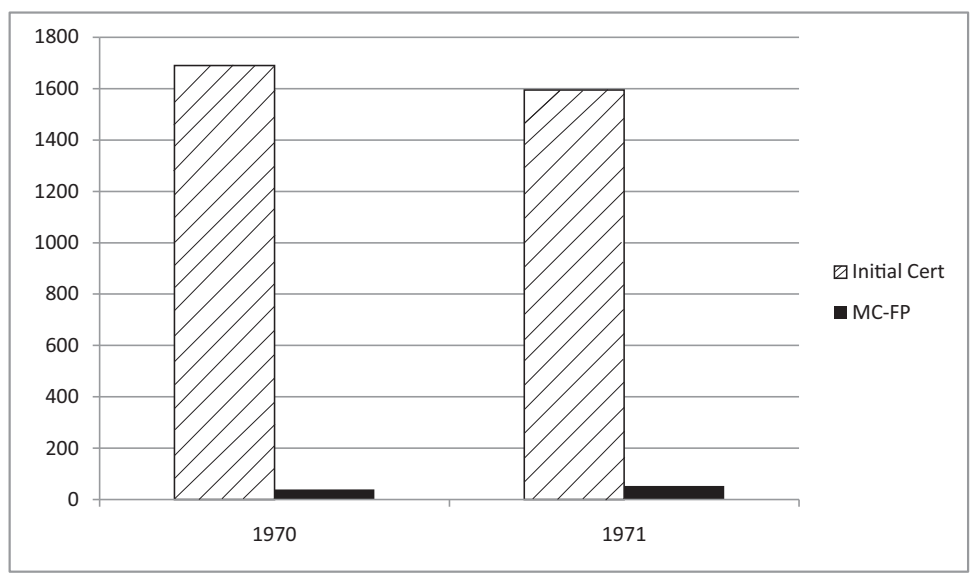

\section{References}

1. Green LA, Puffer JC. Family medicine at forty years of age: the journey to transformation continues. J Am Board Fam Med 2010;23(Suppl):S1-4.

2. Teirstein PS. Boarded to death-why maintenance of certification is bad for doctors and patients. N Engl J Med 2015;373:106-7.

3. Puffer JC, Bazemore AW, Newton W, Makaroff L, Xierali IM, Green LA. Engagement of family physi- cians seven years into maintenance of certification. J Am Board Fam Med 2011;24:483-4.

4. Puffer JC, Bazemore AW, Jaen CR, Xierali IM, Phillips RL, Jones SM. Engagement of family physicians in maintenance of certification remains high. J Am Board Fam Med 2012;25:761-2.

5. Puffer JC, Bazemore AW, Phillips RL, Beebe DK. Certification status of family physicians in the initial cohort entering maintenance of certification. J Am Board Fam Med 2014;27:581-2. 